\title{
PREDICTING DEGRADATION WITH BIOCHEMICAL OXYGEN DEMAND IN DISINFECTANT-POLLUTED SEWAGE
}

\author{
IMOKHAI T. TENEBE ${ }^{1}$, PRAISEGOD CHIDOZIE EMENIKE ${ }^{1}$, DAVID O. OMOLE ${ }^{1}$, \\ NKPA M. OGAREKPE ${ }^{2}$, OMEJE MAXWELL ${ }^{3}$, AIKUOLA A. OLUMUYIWA $^{4}$ \\ \& OMEJE UCHECHUWU ANNE ${ }^{5}$ \\ ${ }^{1}$ Department of Civil Engineering, Covenant University, Nigeria \\ ${ }^{2}$ Department of Civil Engineering, Cross River University of Technology, Nigeria \\ ${ }^{3}$ Department of Physics, Covenant University, Nigeria \\ ${ }^{4}$ Department of Civil Engineering, Federal Polytechnic, Ilaro, Nigeria \\ ${ }^{5}$ National Lottery Regulatory Commission, Lagos zonal Office, Nigeria
}

\begin{abstract}
Most households frequently make use of disinfectants to annihilate infectious bacteria present in toilets and bathrooms. Unfortunately, some of these bacteria may be required for the degradation of sewage in the septic tank system (STS). This paper investigates how the performance (degradation capacity) of sewage will be affected by the inharmonious addition of disinfectants with biochemical oxygen demand (BOD) as the predictor. With a clean 50-litre container, a sewage sample was collected from a waste stabilization pond situated in a Nigerian Tertiary University, transported to the sanitary laboratory in the Department of Civil Engineering, University of Nigeria, Nsukka, and poured into five 4-litre white containers. Different doses of disinfectants $-0.5 \mathrm{ml}, 1 \mathrm{ml}, 1.5 \mathrm{ml}, 2 \mathrm{ml}$, and $2.5 \mathrm{ml}$, were simultaneously added only at the initial day of experimental setup under aerobic conditions, and the $\mathrm{pH}$, dissolved oxygen (DO), disinfectant dose, chemical oxygen demand (COD), and BOD were measured every three days for three weeks. Multivariate analysis was performed on the explanatory variable $-\mathrm{pH}$, DO, disinfectant dosage, and COD - using e-Views 8.0, which revealed that the continuous addition of disinfectants to sewage inhibits its degradation, thereby resulting in increased organic loading within the STS, and may further lead to septic tank failure due to shock loading and a major source of ground water been polluted with emerging contaminants.
\end{abstract}

Keywords: degradation, biochemical oxygen demand, disinfectants, septic tank system, multivariate analysis, sewage pollution.

\section{INTRODUCTION}

A typical septic tank is utilized for the storage and treatment of sewage generated continuously from homes, offices, etc. However, the content in a typical septic tank system (STS) is usually heterogeneous: somewhat polluted with all manner of substance. These substances may include but are not limited to antiseptics, disinfectants, anti-biotics, detergents, etc., which may hamper or annihilate the activities of potent bacteria required for sewage breakdown and could result in septic tank failures. The biochemical oxygen demand (BOD) is defined as the oxygen needed to reduce the organic content present in waste water [1]. Put differently, the BOD also helps to measure the relative strength of bacteria, and shows the degree of contamination in sewage or waste water [2]. Consequently, the health status of a septic tank can be related or measured with the presence of active bacteria, which, in turn, may be related to the rate at which BOD is removed from the system; however, this may be an almost impossible task when the bacteria required is eliminated. Although there is room for re-growth after a disinfection process, because of the presence of organic matter which serves as nourishment for them in the sewage [3]. When bacteria feed on the sewage, there is a reduction in the BOD and chemical oxygen demand (COD) within the STS, whereas the contrary may occur when degradation is lowered. On the other hand, due to the presence of 
germs and bacteria that may be harmful to the health of human beings, it is usually not uncommon to use disinfectants in homes and toilets for improved environmental conditions. From an independent survey, most homes make use of disinfectants for bathing and washing of toilets, and during pour flush and rinsing, they are transported to the STS.

In a study conducted by Agunwamba et al. [4] on the effect of some household disinfectants on aerobic sewage degradation, it revealed that there was an increase in BOD and COD concentration values in the application of disinfectants to sewage, although the strength and the pattern, that is, significance, was not revealed. The implication is that the possibility of proper and timely degradation is unsure. The result was similar when observed under anaerobic conductions with the same disinfectant use [5]. This may be detrimental because dug wells - by hand or boreholes - may be situated around places where STS are found, thereby leading to contamination which should not be condoned [6]. Furthermore, in a study conducted by Tenebe et al. [7] on the sewage performance when polluted with camphor, there was a similar result with that of Agunwamba et al. [5]. In the study, it was reported that a sample container of camphor had less dissolved oxygen than the control samples. This could imply that there is a possibility of more DO used up as the organic content of the sewage increased.

The use of statistical techniques in water resources is not new; however, the application of the Error Correction Method (ECM) is, relatively, not found in the literature on the matter. This method requires limited data and also reduces the anomalies associated in time series analysis. Most experimental work is time dependent, and there is a need to ascertain the degree of data cointegration - checking for both short-run and long-run similarities [8]. Therefore, the study will provide the statistical relationship of the degradation capacity of sewage when polluted with disinfectants of different concentrations with BOD as the predictor BOD between variables using this multivariate technique.

\section{METHODS AND MATERIALS}

\subsection{Experimental set-up}

Sewage from the hostels and some residential quarters is transported through pipes to the treatment units situated in the University of Nigeria campus. A large quantity of sewage was collected with a clean gallon and poured into small transparent containers up to the depths of about $20 \mathrm{~cm}$, and an inharmonious dosage $(0.5 \mathrm{ml}, 1 \mathrm{ml}, 1.5 \mathrm{ml}, 2 \mathrm{ml}$, and $2.5 \mathrm{ml})$ of a wellused disinfectant - Dettol - was added into five different containers with one other set as a control sample; that is, having no disinfectant throughout the experimental period. It would be necessary to mention at this point that the disinfectant was added on the first day of the experimental set-up. Parameters were measured once in every three days for three weeks, and they included: $\mathrm{BOD}, \mathrm{COD}, \mathrm{DO}, \mathrm{pH}$, which was achieved using the standards set by APHA (1985).

\subsection{Data analysis}

The analysis of data was conducted using e-Views 8.0. Normality of the individual variables was tested using the Jarque-Bera test, and the presence or absence of auto-correlation, as well as heteroscedasticity, was achieved using the Breusch-Godfrey Serial Correlation LM Test and Breusch-Pagan-Godfrey test, respectively. Also, the unit root test and cointegration test was conducted using the Augmented Dickey-Fuller test (ADF) and Johansen cointegration test, respectively. 


\section{RESULTS AND DISCUSSION}

The descriptive statistics in Table 1 reveal that BOD, COD, $\mathrm{pH}$, disinfectant dosage and DO have their mean values to be: $200.67 \pm 56.15,305.50 \pm 86.2,9.13 \pm 0.69,1.50 \pm 0.71$, and $2.71 \pm 1.48$ respectively.

Furthermore, a normality test was conducted using the Jarque-Bera standard, which revealed that only disinfectant dosage and DO are not normally distributed; that is, $p>0.05$, while BOD, COD, and $\mathrm{pH}$ expressed symmetrical shapes when plotted.

In order to ascertain the contributing variables to be included in the model, dimension reduction analysis was conducted using the principal component analysis (PCA). From Table 2, collectively, the variables are grouped into five different groups - PC1-PC5. In PC1, it is hypothesized that all the variables are contributors; therefore, the strength of the variables cannot be judged from that group. However, after considering PC2-PC5 from the loadings (Table 2), results revealed that disinfectant dosage ( $\mathrm{ml}), \mathrm{DO}(\mathrm{mg} / \mathrm{l}), \mathrm{COD}(\mathrm{mg} / \mathrm{l})$, and BOD $(\mathrm{mg} / \mathrm{l})$ are among the variables actively contributing to the present sewage properties with

Table 1: Descriptive statistics of the variables measured.

\begin{tabular}{l|l|l|l|l|l}
\hline & BOD & COD & Disinfectant dose & DO & pH \\
\hline Mean & 200.67 & 305.50 & 1.50 & 2.71 & 9.13 \\
\hline Median & 186.00 & 266.00 & 1.50 & 2.55 & 8.90 \\
\hline Maximum & 341.00 & 516.00 & 2.50 & 5.80 & 10.60 \\
\hline Minimum & 109.00 & 212.00 & 0.50 & 0.30 & 8.40 \\
\hline Std. dev. & 56.15 & 86.2 & 0.71 & 1.48 & 0.69 \\
\hline Skewness & 1.03 & 1.06 & 0.35 & 0.51 & 1.24 \\
\hline Kurtosis & 3.34 & 2.96 & 1.70 & 2.52 & 2.95 \\
\hline Jarque-Bera & 7.39 & 7.58 & 2.81 & 2.13 & 10.27 \\
\hline Probability & 0.02 & 0.02 & 0.24 & 0.34 & 0.00 \\
\hline Sum & 8027.00 & 12220.00 & 60.00 & 108.50 & 365.30 \\
\hline Sum Sq. Dev. & 122990.8 & 289846.0 & 20.00 & 86.38 & 19.00 \\
\hline
\end{tabular}

Table 2: Principal component analysis.

Eigenvalues:

\begin{tabular}{l|l|l|l|l|l}
\hline Number & Value & Difference & Proportion & Cumulative value & Cumulative proportion \\
\hline 1 & 2.01 & 0.64 & 0.40 & 2.01 & 0.40 \\
\hline 2 & 1.37 & 0.56 & $\mathbf{0 . 2 7}$ & 3.37 & 0.67 \\
\hline 3 & 0.81 & 0.23 & $\mathbf{0 . 1 6}$ & 4.18 & 0.85 \\
\hline 4 & 0.58 & 0.3 & $\mathbf{0 . 1 2}$ & 4.76 & 0.95 \\
\hline 5 & 0.24 & - & $\mathbf{0 . 0 5}$ & 5.00 & 1.00 \\
\hline
\end{tabular}

Eigenvectors (loadings):

\begin{tabular}{l|l|l|l|l|l}
\hline Variable & PC 1 & PC 2 & PC 3 & PC 4 & PC 5 \\
\hline BOD & 0.63 & 0.02 & 0.18 & -0.37 & $\mathbf{0 . 6 6}$ \\
\hline COD & 0.51 & 0.15 & -0.34 & $\mathbf{0 . 7 7}$ & 0.03 \\
\hline DO & 0.22 & -0.57 & $\mathbf{0 . 7 1}$ & 0.29 & -0.22 \\
\hline Disinfectant dose & 0.37 & $\mathbf{0 . 6 3}$ & 0.30 & -0.21 & -0.57 \\
\hline pH & -0.39 & 0.51 & 0.51 & 0.37 & 0.43 \\
\hline
\end{tabular}


the values: 0.63 (PC2), 0.71 (PC3), 0.77 (PC4), and 0.66 (PC5) respectively. Likewise, from the eigenvalues (Table 2), it is further revealed that the proportion contributed in those components are: $0.27,0.16,0.12$, and 0.05 . On the other hand, it may be too quick to conclude that the effect of disinfecting the sewage did not affect the $\mathrm{pH}$ values, therefore suggesting that $\mathrm{pH}$ should not be in our model. This decision is because this is an experimental study, and every variable should have a role. Also, since the PCA did not indicate the probability, it is still worth trying it in our model.

As suggested by Newbold and Granger [9], there is a need to check for the stability of data sets as they tend not to be stationarity over time, especially experimental data. Be that as it may, a stationarity test uses the widely used and accepted ADF test at first or second difference, of which any could be likely [10]. In this analysis, the collective datasets of the variables were stationary at first difference, and this is summarised in the ADF statistical table (Table 3).

Furthermore, the cointegration level over time of the dataset was checked using the Johansen cointegration test. This is represented in Table 4 . The test reveals that the variables to be used in our model have long run relationships $(p=0.01 ; 0.05)$ and are adequate to produce the supposed result - three cointegration variables. Therefore, we can introduce this adjusted dataset using the Error Correction Method to cushion the effect caused by the data manipulation for further statistical analysis and modelling.

The sensitivity values of the variables as well as the ECM modelled data is tabulated in Table 5. From the table, it shows that the coefficient of COD is 0.189 . This means that for every $1 \%$ increase in BOD, there will be a corresponding increase in COD by 0.189 . This is further emphasized by the value of the $t$-statistics. With a value of 3.3855 , this result is significant at $1 \%$. In the same vein, when the relationship between DO and BOD was considered, there exists a positive relationship between them. The value of the DO coefficient is 0.007 . This implies that for a $1 \%$ increase in DO, the BOD values will increase by $0.007 \%$. This may be uncommon because the DO presence should normally bring about degradation as micro-organisms are feeding on the organic content while using up oxygen. Unfortunately, in this case, the DO presence is hardly felt even though the $t$-value (3.776) reveals its significance at the $1 \%$ level. The reason may be due to the thin film introduced by the addition of disinfectant which probably reduces the rate of oxygen transfer in the air-water interface [7]. However, there is a possibility of the STS being without disinfectant and having sufficient oxygen as there is little or no hindrance in oxygen transfer. Interestingly, when the disinfectant dose was put in perspective, it showed a positive relationship with BOD, with a coefficient of 0.674 . Statistically, it implies that a $1 \%$ increase in disinfectant concentration

Table 3: Augmented Dickey-Fuller test summarised at first difference.

\begin{tabular}{|c|c|c|c|c|c|}
\hline \multirow[t]{2}{*}{ Variables } & \multirow{2}{*}{$\begin{array}{l}\text { ADF test } \\
\text { statistics }\end{array}$} & \multicolumn{2}{|c|}{ ADF critical values } & \multirow[t]{2}{*}{ Remark } & \multirow{2}{*}{$\begin{array}{l}\text { Order of } \\
\text { integration }\end{array}$} \\
\hline & & $1 \%$ level & $5 \%$ level & & \\
\hline D(BOD) & -14.00 & -3.62 & -2.94 & Stationary & $\mathrm{I}(1)$ \\
\hline D(COD) & -6.26 & -3.62 & -2.94 & Stationary & $\mathrm{I}(1)$ \\
\hline $\begin{array}{l}\mathrm{D}(\text { disinfectant } \\
\text { dose) }\end{array}$ & -6.75 & -3.62 & -2.94 & Stationary & $\mathrm{I}(1)$ \\
\hline $\mathbf{D}(\mathbf{D O})$ & -10.99 & -3.62 & -2.94 & Stationary & $\mathrm{I}(1)$ \\
\hline $\mathrm{D}(\mathrm{pH})$ & -6.04 & -3.62 & -2.94 & Stationary & $\mathrm{I}(1)$ \\
\hline
\end{tabular}

Null hypothesis: state not stationary when ADF critical values $>$ ADF test statistics. 
Table 4: Cointegrations test for long-run relationship of model variables.

\begin{tabular}{lllll}
\hline \hline $\begin{array}{l}\text { Hypothesized } \\
\text { no. of CE(s) }\end{array}$ & Eigenvalue & Trace statistic & $\begin{array}{l}\mathbf{5 \%} \text { critical } \\
\text { value }\end{array}$ & $\begin{array}{l}\mathbf{1 \%} \text { critical } \\
\text { value }\end{array}$ \\
\hline \hline None** & 0.89 & 188.16 & 68.52 & 76.07 \\
At most $1^{* *}$ & 0.75 & 103.89 & 47.21 & 54.46 \\
At most 2** & 0.66 & 50.54 & 29.68 & 35.65 \\
At most 3 & 0.19 & 9.10 & 15.41 & 20.04 \\
At most 4 & 0.03 & 1.07 & 3.76 & 6.65 \\
\hline \hline
\end{tabular}

Trace test indicates 3 cointegrating equation(s) at both $5 \%$ and $1 \%$ levels. $*(* *)$ denotes rejection of the hypothesis at the $5 \%(1 \%)$ level.

\begin{tabular}{lllll}
\hline \hline $\begin{array}{l}\text { Hypothesized } \\
\text { no. of CE(s) }\end{array}$ & Eigenvalue & $\begin{array}{l}\text { Max-eigen } \\
\text { statistic }\end{array}$ & $\begin{array}{l}\mathbf{5 \%} \text { critical } \\
\text { value }\end{array}$ & $\begin{array}{l}\mathbf{1 \%} \text { critical } \\
\text { value }\end{array}$ \\
\hline \hline None** & 0.89 & 84.27 & 33.46 & 38.77 \\
At most $1^{* *}$ & 0.75 & 53.35 & 27.07 & 32.24 \\
At most 2** & 0.66 & 41.44 & 20.97 & 25.52 \\
At most 3 & 0.19 & 8.04 & 14.07 & 18.63 \\
At most 4 & 0.03 & 1.07 & 3.76 & 6.65 \\
\hline \hline
\end{tabular}

$*(* *)$ denotes rejection of the hypothesis at the $5 \%(1 \%)$ level.

increased the BOD level by $0.674 \%$. Consequently, every addition of disinfectant increases the organic concentration of the sewage in the STS. Although in this study the effect of this disinfectant in terms of either inactivating or annihilating the bacteria was not analysed, there is the possibility of the latter situation occurring within the system. Furthermore, the $t$-value of 3.69 shows that it is also very significant at the $1 \%$ level. The $\mathrm{pH}$ was also considered as a factor. It indicated that there is an inverse relationship between the BOD as the predictor and the $\mathrm{pH}$ values recorded by 2.294 . This implies that an increase in $\mathrm{pH}$ by $1 \%$ will mean that the BOD will be decreased by $2.294 \%$. Likewise, the $t$-statistic (9.931) reveals that this factor is considered very significant and important for predicting the BOD level in a STS.

The ECM in the equation derived is -0.007 and significant with a $t$-value of 10.35 . This satisfies the condition that any given equation should be negative and significant before it can be accepted. It also assists to cushion the speed of adjustment made during the conversion of the variables from one form to another. Lastly, the $R^{2}$ value and the Durbin-Watson statistics of the model generated is 0.951 and 1.89 respectively. This implies that $95 \%$ of the overall performance of the variables used well explains the BOD performance. Also, the value of the Durbin-Watson statistics reveals that auto-correlation is expunged from the model. The model generated is in the form below. Eqn (1) shows the representation of the correction model:

$$
\begin{array}{r}
D(L N B O D)_{t}=\beta_{o}+\beta_{1 i} \sum_{i=0}^{n} D(L N C O D)_{t}+\beta_{2 i} \sum_{i=0}^{n} D(L N D O)_{t}+\beta_{3 i} \sum_{i=0}^{n} D(L N D I S I N F E C T A N T \text { DOSE })_{t} \\
+\beta_{4 i} \sum_{i=0}^{n} D(L N p H)+E_{C M}(-1),
\end{array}
$$


where $i=1,2,3 \ldots n$. Also:

$\beta_{o}=$ cons $\tan t$ or int ercept

$\beta_{1 i}=$ coefficient of $\operatorname{COD}(\mathrm{mg} / \mathrm{l})$

$\beta_{2 i}=$ coefficient of $\mathrm{DO}(\mathrm{mg} / \mathrm{l})$

$\beta_{3 i}=$ coefficient of Disin fectan $t$ dose $(\mathrm{ml})$

$\beta_{44 i}=$ coefficient of $\mathrm{pH}$

Table 5: Sensitivity analysis of variables using ECM.

Dependent Variable: D_LNBOD

Method: Least squares

Convergence achieved after 114 iterations

HAC standard errors and covariance (Bartlett kernel, Newey-West fixed bandwidth = 4.0000)

MA Backcast: 67

\begin{tabular}{|c|c|c|c|c|}
\hline Variable & Coefficient & Std. error & $t$-statistic & Prob. \\
\hline $\mathbf{C}$ & 0.01 & 0.01 & 0.76 & 0.45 \\
\hline D(LNCOD) & 0.19 & 0.06 & 3.39 & 0.00 \\
\hline D(LNDO) & 0.07 & 0.02 & 3.78 & 0.00 \\
\hline D(LNDISINFECTANT & 0.67 & 0.18 & 3.69 & 0.00 \\
\hline DOSE) & & & & \\
\hline D(LNPH) & -2.29 & 0.23 & -9.93 & 0.00 \\
\hline ECM & -0.01 & 0.01 & -10.35 & 0.00 \\
\hline $\operatorname{AR}(7)$ & -0.63 & 0.09 & -7.24 & 0.00 \\
\hline MA(2) & -0.93 & 0.04 & -24.95 & 0.00 \\
\hline$R$-squared & 0.95 & \multirow{8}{*}{\multicolumn{2}{|c|}{$\begin{array}{l}\text { Mean dependent var. } \\
\text { SD dependent var. } \\
\text { Akaike info criterion } \\
\text { Schwarz criterion } \\
\text { Hannan-Quinn criteria } \\
\text { Durbin-Watson stat. } \\
\text { Wald F-statistic }\end{array}$}} & 0.01 \\
\hline Adjusted $R$-squared & 0.94 & & & 0.40 \\
\hline $\mathrm{SE}$ of regression & 0.10 & & & -1.52 \\
\hline Sum-squared resid. & 0.25 & & & -1.15 \\
\hline Log likelihood & 32.29 & & & -1.40 \\
\hline$F$-statistic & 66.24 & & & 1.89 \\
\hline $\operatorname{Prob}(F$-statistic $)$ & 0.00 & & & 81.30 \\
\hline Prob(Wald F-statistic) & 0.00 & & & \\
\hline \multirow[t]{2}{*}{ Inverted $\mathrm{AR}$ roots } & $0.85-0.41 \mathrm{i}$ & $0.85+0.41 \mathrm{i}$ & $0.21-0.92 \mathrm{i}$ & $0.21+0.92 \mathrm{i}$ \\
\hline & $-0.59+0.74 \mathrm{i}$ & $-0.59-0.74 \mathrm{i}$ & -0.95 & \\
\hline Inverted MA roots & 0.96 & -0.96 & & \\
\hline
\end{tabular}


The test conducted and tabulated in Table 6 is used to determine the presence of auto-correlation in our new model. The presence of auto-correction in any modelled dataset is mostly found in a simple or multiple regression equation(s) and should not be condoned as the modelled result obtained may result in spurious analysis and conclusions. Therefore, the auto-correlation was tested for after the correction by the ECM. As it stands, from Table 7, since $P>0.05$, it suggests that the alternative hypothesis will accept that there is no auto-correlation in our model. Likewise, owing to data variability and environmental conditions, there is bound to be a disparity in the datasets. Therefore, the issue of heteroscedasticity should be addressed. This is also one of the major problems of most multiple regression equations. Most equations are derived on the assumption of homoscedasticity of variables and dataset. Be that as it may, heteroscedasticity was tested for using the Breusch-Pagan-Godfrey test. From Table 6, it is revealed that there is no heteroscedasticity present in the derived model, further strengthening its correctness.

\section{CONCLUSION AND RECOMMENDATIONS}

The daily use of disinfectants in homes and offices cannot be overemphasized. When this occurs, they are transported to the STS for possible treatment. This paper presents the use of BOD for the prediction of sewage degradation when sewage is polluted with a disinfectant. From the study, it revealed that there is a very large (negative) contribution of disinfectant inclusion in the sewage $(t=3.69$; coefficient $=0.674)$ as there is an increase in BOD concentration. This further connotes that there will be an increase in organic loading within the STS, thereby leading to shock loading. Furthermore, the disinfectant activity also adversely affected the DO and COD concentration, as little or no degradation are taking place. With this, there is a possible infiltration of toxic substance inherent in the system into groundwater channels, thereby likely to pose a health risk to those who will drink the contaminated groundwater. Also, it is worth mentioning that although the study was carried out with only a single dosing of the sewage samples, it is clear that this may not be the true case of the real-life conditions; that is, the conditions are even worse, as there is constant use of disinfectant in homes and offices, thereby prognosticating a worse scenario than that which was envisaged by this study. Therefore, future work should include the effect of constant dosing of some other household disinfectants both on sewage and bacteria that may be responsible for the degradation process, water quality assessment for presence of some compound that makes up the disinfectant used within an area where STS is available, as well as the possible health risk assessments should be conducted. Finally, home users should be well educated about the proper and effective use of disinfectants, while manufacturers should improve their products by putting the health status of STS in perspective.

Table 6: Breusch-Godfrey Serial Correlation LM Test.

\begin{tabular}{llll}
\hline \hline -statistic & 0.43 & Prob. F(1,24) & 0.52 \\
Obs* $R$-squared & 0.56 & Prob. chi-square(1) & 0.45 \\
\hline \hline
\end{tabular}

*Null hypothesis: accept null hypothesis that there is no auto-correlation when $P>0.05$.

Table 7: Heteroskedasticity test: Breusch-Pagan-Godfrey.

\begin{tabular}{llll}
\hline \hline$F$-statistic & 0.76 & Prob. F(5,26) & 0.59 \\
Obs* $R$-squared & 4.08 & Prob. chi-square(5) & 0.54 \\
Scaled explained SS & 1.55 & Prob. chi-square(5) & 0.91 \\
\hline \hline
\end{tabular}

*Null hypothesis: accept null hypothesis that there is no heteroscedasticity when $P>0.05$. 


\section{ACKNOWLEDGEMENT}

The authors wish to thank the management of Covenant University for their support towards achieving this research work and for us to be present at the conference.!

\section{REFERENCES}

[1] Omole, D.O., Badejo, A.A., Ndambuki, J.M., Musa, A.G. \& Kupolati, W.K., Analysis of auto-purification response of the Apies River, Gauteng, South Africa, to treated wastewater effluent. Water SA, 42(2), p. 225, 2016.

[2] Lin, S.D. \& Lee, C.C., Water and Wastewater Calculations Manual, 2nd ed., McGrawHill: New York, pp. 1-15, 2007.

[3] Yasar, A. \& Tabinda, A.B., An aerobic treatment of industrial wastewater by UASB reactor integrated with chemical oxidation processes; an overview. Polish J. of Environ. Stud., 19(5), pp. 1051-1061, 2010.

[4] Agunwamba, J.C., Tenebe, I.T. \& Emenike, P.C., Effect of disinfectants on aerobic sewage degradation using Dettol and Izal as case study. Int. J. Struct. \& Civil Eng. Res., 2(4), pp. 164-194, 2013.

[5] Agunwamba, J.C., Oge, S.O., Ume, C.U. \& Ugwuanyi, S.E., Effect of disinfectant on anaerobic degradation of wastewater. International Journal of Engineering Sciences \& Research Technology, 3(8), pp. 814-823, 2014.

[6] Tenebe, I.T., Ogbiye, A.S., Omole, D.O. \& Emenike, P.C., Estimation of longitudinal dispersion co-efficient: A review. Cogent Engineering, 3(1), pp. 1-16, 2016.

[7] Tenebe, I.T., et al., Assessment of dissolved oxygen in sewage containing camphor. $3^{\text {rd }}$ International Conference on African Developmental Studies (CU-ICADI), pp. 527533, 2016.

[8] Parajuli, R., Chang, S.J. \& Hill, R.C., How effective is the United States-Canada Softwood Lumber Agreement 2006? An econometric study. Forest Science, 61(6), pp. 1041-1049, 2015.

[9] Newbold, P. \& Granger, C.W., The time series approach to econometric model building. Essays in Econometrics, pp. 302-316, 2001.

[10] Johansen, S. \& Juselius, K., Maximum likelihood estimation and inference on cointegration - with applications to the demand for money. Oxford Bulletin of Economics and Statistics, 52(2), pp. 169-210, 2009.

[11] Ogarekpe, N., Agunwamba, J. \& Nwaogazie, I., Sensitivity analysis of model parameters on biochemical oxygen demand in integrated solar and hydraulic jump enhanced waste stabilization pond. Desalination and Water Treatment, pp. 1-13, 2015. 